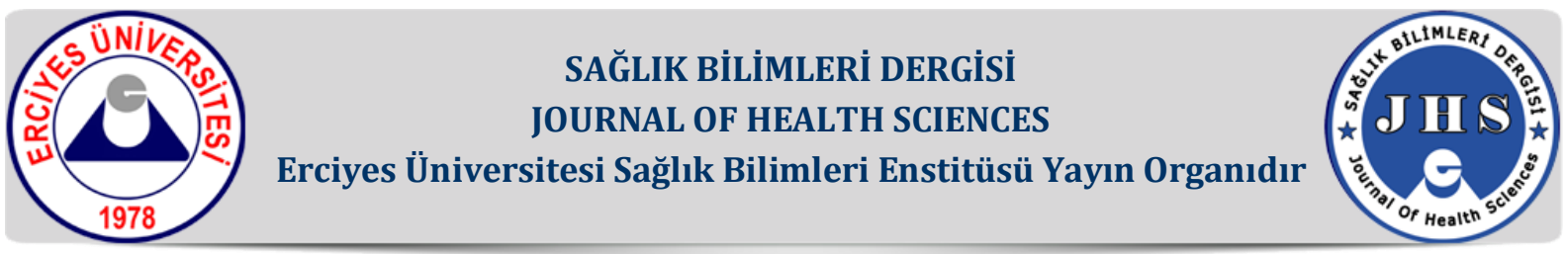

Araștırma Yazısı

$2021 ; 30: 9-16$

\title{
ANNE VE BABA ADAYLARININ GEBE OKULUNA KATILMA VE KATILMAMA NEDENLERINIIN BELİRLENMESİ: AYDIN İLİ ÖRNEĞí \\ IDENTIFYING THE REASONS OF FUTURE MOTHERS AND FATHERS TO PARTICIPATE AND NOT PARTICIPATE IN PREGNANCY SCHOOL: THE SAMPLE OF AYDIN PROVINCE
}

\author{
Sibel ŞEKER', Funda ÇíTÍL CANBAY², Ceylan CESUR', Nasim FİROUZ1
}

\author{
${ }^{1}$ Aydın Adnan Menderes Üniversitesi Sağlık Bilimleri Fakültesi, Aydın \\ ${ }^{2}$ Atatürk Üniversitesi Sağlık Bilimleri Fakültesi, Erzurum
}

\section{öz}

Araştırma anne ve baba adaylarının gebe okuluna katılma ve katılmama nedenlerinin belirlenmesi amaciyla yapıldı. Araștırma, tanımlayıcı tipte gerçekleștirildi. Örnekleme 100 çift alındı. Verilerin toplanmasında "Anne Adayı Bilgi Formu" ve" Baba Adayı Bilgi Formu" kullanıldı. Analizde tanımlayıcı istatistikler ve ki-kare analizi kullanıldı. Gebe okuluna katılan baba adaylarının ebeveynlik (\%25), eșe destek olmak (\%25) ve tüm süreçle ilgili bilgi almak (\%25) amacıyla gebe okuluna başvurduğu belirlendi. Gebe okuluna katılan anne adayları ise, çoğunlukla doğum korkusu (\%26.5) ve tüm süreçle ilgili bilgi almak (\%26.5) için gebe okuluna katıldığı belirlendi. Gebe okuluna katılmayan anne adaylarının \%20.7'si uygulamayı duymadığı için gebe okuluna katılmadığı belirlendi. Baba adaylarının \%50.6'sı iş yoğunluğu nedeniyle gebe okuluna katılmadığını bildirdi. Katılımcıların gebe okuluna katılma durumu, katılma ve katılmama nedenleri bakımından istatistiksel açıdan anlamlı olduğu saptandı $(\mathrm{p}<0.05)$. Katılımcıların çoğunlukla gebe okuluna katılmadığı ve gebe okulu hakkında yeterli bilgi sahibi olmadığı belirlendi.

Anahtar kelimeler: Baba adayı, ebe, gebe, gebe okulu, hemşire.

\section{ABSTRACT}

This research was done to identify the participation and non-participation reasons of future mother and father in pregnancy school. The research was done in descriptive type. The sample included 100 couples. "Future Mother Information Form" and "Future Father Information Form" were used in data collection. Descriptive statistics and chi-square analysis were used in data analysis. It was established that the future fathers applied to the pregnancy school for reasons such as parenthood $(25 \%)$, supporting partner $(25 \%)$ and receiving information about the whole process. It was also established that future mothers mostly applied to the pregnancy school for delivery fear $(26.5 \%)$ and to receive information about the whole process $(26.5 \%)$. It was found that the future mothers with nonparticipation in the pregnancy school had reason such as program not hearing about it (20.7\%). $50.6 \%$ of the future fathers stated that they did not attend the pregnancy school because of their heavy workloads. The participants' attendance was found statistically significant in terms of the grounds of participation and nonparticipation in the pregnancy school $(\mathrm{p}<0.05)$. It was discovered that participants in the pregnancy school was not substantial and future husbands did not have sufficient knowledge about the pregnancy school.

Keywords: Future father, midwife, nurse, pregnant, pregnancy school.
Corresponding Author: Arş.Gör.Dr. Funda ÇİTİL CANBAY, ORCID: 0000-0001-7520-4735, Atatürk Üniversitesi Sağlık Bilimleri Fakültesi, Erzurum/TÜRKIYE,

E-mail: Midwifefunda23@gmail.com Dr. Öğr. Üyesi Sibel ŞEKER, ORCID: 0000-0001-8730-1786

Ebe Ceylan CESUR, ORCID: 0000-0003-1724-3845 Ebe Nasim FIROUZ, ORCID: 0000-0001-5910-577X 


\section{GíRiş}

Her gebenin doğumunu güvenli koşullarda gerçekleştirmek, nitelikli sağlık hizmetlerinden yararlanabilmek ve güzel anılarla pozitif bir doğum deneyimi yaşamak en doğal hakkıdır (1). Her gebelikte ortaya çıkabilecek bazı riskler bulunmakla beraber, daha çok gelișmekte olan ülkelerde morbidite ve mortaliteye neden olabilecek önlenebilir komplikasyonlar ortaya çlkabilir. Bu komplikasyonları ve riskleri önceden tespit etmek adına doğum öncesi bakım hizmetlerinden yararlanmak önem taşır. Bu doğrultuda doğum öncesi bakım, gebelik süresince gebelerin düzenli aralıklarla (8 temas) gerekli temasların (2) yapılarak uygun bakım ve eğitimlerin sağllk profesyonelleri tarafindan sağlanarak izlendiği bireyselleştirilmiş bakım uygulanmalıdır (3-5). Gebe bilgilendirme sınıfları ya da okullarındaki eğitimlerde gebelere ve eşlerine; gebelik, doğum ve sonrası dönemle ilgili konularda bilgi gereksinimlerinin karşılanmasıyla, ebeveynlere yönelik faydalı davranıș özelliklerinin kazandırılması ve ebeveynlik konularında bilgi ve beceri kazandırmak amaçlanmaktadır $(6,7)$.

Genel anlamda bu sınıflarda sunulan eğitim programları gebelik haftasına ve ailelere özel olarak düzenlenmiș olmalıdır (8). Doğum öncesi dönemde gebe ve eșlerinin bu eğitimlere katılması, sağlık kuruluşlarında yapılan gebe okulları çalıșmalarının artırılması ve baba adaylarının da bu okullara katılmalarının sağlanmasının doğum öncesi bakımın kalitesinin artmasına katkı sağlayacaktır (9-11). Bu bağlamda sağlık kurumlarında gebe ve eșlerinin bu eğitim programlarına katılımının yaygınlaștırılması, sağlık personeline bu programların tanıtılması ve gebelerin de doğum öncesi bakım eğitimlerine katılımının özendirilmesi gerekmektedir $(8,10)$. Ancak çoğu ülkede gebeler ve eşleri bu eğitimlere çeşitli nedenlerle katılamamaktadır. Özellikle baba adayları kültürel, kişisel, ekonomik ve sağllk sistemiyle ilgili engeller nedeniyle doğum öncesi eğimlere katılamamaktadırlar $(9,12)$. Türkiye'de 2018 yılında yapılan bir araştırmada gebe eğitim sınıflarına katılan yüz seksen gebenin; spontan vajinal doğuma ilişkin farkındalıkları artmış, doğum süreleri kısalmıș, ilk emzirme zamanı ve ten tene temasa ilişkin olumlu davranış özellikleri görülmüştür (13). Bu bağlamda gebeler doğum tercihi konusunda spontan vajinal doğumu tercih etmişlerdir (13). Gebeler ve eşlerinin dahil edildiği yarı deneysel kontrol gruplu bașka bir çalışmada, doğum öncesi ve sonrası sürece aktif katılımı teşvik etmek amaçlanmış olup, 128 baba adayının çoğunluğu eğitimlerin bilgi gereksinimlerini karşıladıklarını bildirerek, eşe destek olma konusunda ve ebeveynlik konusunda daha az endişe yaşadıklarını bildirmişlerdir (14).

Doğum öncesi eğitimlere katılımın yeterli düzeyde olmadığı bilinmektedir $(15,16)$. Literatürde bireylerin gebe okuluna katılma nedenlerinin irdelendiği herhangi bir çalışmaya rastlanmamıștır. Bu bağlamda öngörümüz araştırmamızın sonuçlarının; gebelerin ve eșlerinin gebe okuluna katılma ve katılmama nedenlerinin belirlenmesine yönelik bilgi sağlamasının yanında, elde edilen bilgiler ailelerin gebe okulu eğitim programlarına katılımlarının özendirilmesinin ve meydana gelebilecek aksaklıklar konusunda gebe okulu planlayan sağlık profesyonellerine yol göstermesi açısından önemli olabilir. Bu bağlamda bu araștırma ile anne ve baba adaylarının gebe okuluna katılmama nedenlerinin belirlenmesi amaçlandı. Bu amaç doğrultusunda şu sorulara cevap arandi: (I.) Anne ve baba adaylarının gebe okullarına katılma gereksinimine yönelik bilgi ve görüșleri nelerdir, (II.) Anne ve baba adaylarının gebe okuluna katılma nedenleri nelerdir ve (III.) Anne ve baba adaylarının gebe okuluna katılmama nedenleri nelerdir?

\section{GEREÇ VE YÖNTEM \\ Araştırmanın Tipi}

$\mathrm{Bu}$ araştırma, anne ve baba adaylarının gebe okuluna katılma ve katılmama nedenlerinin belirlendiği tanımlayıcı tipte bir çalışmadır.

\section{Araștırmanın Evreni ve Örneklemi}

Çalışmanın evrenini; Sağlık Bakanlığı İl Sağlık Müdürlüğü'ne bağlı bir Kadın Doğum ve Çocuk Hastalıkları Hastanesi'ne izlem için bașvuran anne ve baba adayları oluşturdu. Örnekleme dâhil edilenen az katılımcı sayısı; daha önce benzer bir çalıșma yapılmamıș olduğundan GPower 3.1.3 ile ki-kare analizi için etki büyüklüğü $\mathrm{w}=0.3$ (orta etki) alınarak $\% 95$ güven aralığında, $\alpha=0.05$ ve df:3, \%80 güç için 122 olarak hesaplandı $(17,18)$. Araştırma olası veri kayıpları dikkate alınarak 15 Haziran 2019-30 Kasım 2019 tarihleri arasında 200 kiși (100 anne ve 100 baba) ile tamamland. Veri toplama tarihleri içerisinde sırayla 128 anne adayı, 110 baba adayı araștırmaya katılmaya davet edilmiș olup araștırma kriterlerine uygun ve araştırmaya katılmayı kabul eden 200 katılımcı ile araștırma gerçekleștirildi. Araștırmaya;18 yaș ve üstünde olan, Türkçe konuşup, okuyup, anlayabilen ve yazabilen, tek ve sağlıklı bir bebek bekleyen, araștırma kriterlerine uygun, araștırmayı katılmaya gönüllü ve istekli tüm anne ve baba adayları dâhil edildi. Veri Toplama Aracının Uygulanması

Verilerin toplanmasında; "Anne Adayı Bilgi Formu" ve"Baba Adayı Bilgi Formu" kullanıldı. "Baba Adayı Bilgi Formu" (24 soru) ve "Anne Adayı Bilgi Formu" (24 so$\mathrm{ru})$; araștırmaya katılan anne ve baba adaylarının sosyo -demografik özellikleri ile gebe okuluna katılma ve katılmama nedenlerine ilișkin verileri toplamak amaciyla literatür bilgileri doğrultusunda $(7,8,13,19,20)$ araştırmacılar tarafından hazırland.. Ek olarak veri toplama formu gebelerin mevcut gebeliği ve doğurganlık öykülerini içeren sorular içermektedir. Ebelik alanında doktora mezunu üç uzmandan veri toplama formları hakkında görüş alındı. Alınan öneriler doğrultusunda veri toplama araçları yeniden düzenlendi. Veri toplama formunda şu soruları içeriyordu:

- Gebelik, doğum, doğum sonu dönem ve ebeveynlik hakkında yeterli bilgiye sahip olduğunuzu düşünüyor musunuz?

- Gebelik, doğum ve doğum sonu dönem hakkındaki bilgilerinizi nereden edindiniz?

- Gebe okulu ya da gebe bilgilendirme sınıflarını duydunuz mu?

- $\quad$ Bugüne kadar herhangi bir yerden siz veya eşiniz gebe okulu hakkında bilgi aldınız mı?

- Gebe okulu hakkında bilgi almak ister miydiniz? (Yazınız hangi konularda)

- Gebe okuluna katılmama nedenlerinizi yazınız? $\mathrm{Ne}$ önerirsiniz? (Gebe okuluna katılmayanlar için)

- Gebe okuluna katılma nedenleriniz nelerdir? Ne önerirsiniz? (Gebe okuluna katılanlar için) 
Araștırmanın yapıldığı hastanedeki uygun bir odada araștırmaya katılmayı kabul eden katılımcılardan nicel veriler anket formunu özbildirim yöntemi ile doldurmaları sağlandı. Anket formunun doldurulması toplam 1015 dakika almaktadır. Anne ve baba adayları ile görüşmeler ayrı ayrı yapılmış olup, görüşme sırasında farklı ortamlarda olmaları sağlandı.

\section{İstatistiksel Analiz}

Analiz bilgisayar ortamında, IBM SPSS (Versiyon 22.0) istatistik paket programında yapıldı. Verilerin istatistiksel analizinde tanımlayıcı istatistikler ve ki-kare analizi kullanıldı. İstatistiksel anlamlılık düzeyi olarak p $<0.05$ kabul edildi.

\section{Araştırmanın Etik Boyutu}

Çalışmanın yapılabilmesi için Aydın Adnan Menderes Üniversitesi Sağlık Bilimleri Fakültesi Etik Kurulu Bașkanlığı'ndan 21.06.2019 tarih ve 92340882-050.04.04 sayılı onay alındı. Araştırmanın kurum izni araștırmanın yapıldığı șehirdeki il sağlık müdürlügünden alındı. Araştırmaya katılan bireylerden yazılı ve sözlü olarak aydınlatılmıș onamları alındı.

\section{BULGULAR}

Anne ve baba adaylarının gebe okuluna katılma ve katılmama nedenlerine ilişkin katılımcıların görüşlerinin incelendiği araştırmadan elde edilen sonuçlar ve istatistiksel analizler tablolar halinde sunuldu.

Araștırma kapsamına alınan gebelerin yaș ortalaması $27.40 \pm 5.74$ ve baba adaylarının ise $30.55 \pm 5.93$ olarak hesaplandı. Gebelerin\%26'sı lise, \%26'sı üniversite mezunu olduğu, baba adaylarının ise $\% 25$ 'inin ortaokul ve \%34'ünün lise mezunu olduğu belirlendi. Anne adaylarının \%22'si, baba adaylarının ise \%97'si ise gelir getiren bir işte çalışmaktaydı. Anne adaylarının \%84'ünün ve babaların \%87'sinin sağlık güvencesi vardı. Anne adaylarının çoğunluğu (\%57), benzer șekilde baba adaylarının \%70'i gelirinin giderini karşıladığını bildirdi. Anne adaylarının en uzun süre yașadığı yer il (\%48) olup, benzer şekilde baba adayları da en uzun süre yaşadığı yerin il (\%58) olduğunu bildirmiştir (Tablo I).

Anne adaylarının mevcut gebeliğe ilișkin anne adaylarının \%94'ü, baba adaylarının ise \%91'i bu gebeliği istediğini bildirdi. Anne adaylarının \%77'si, baba adaylarının $\% 75$ 'i bu gebeliğin planlı olduğunu belitti. Anne ve baba adayları birden fazla kaynaktan bilgi edindiklerini bildirmiş olup, anne adaylarının \%67'si sağlık profesyonellerinden bilgi edindikleri belirlendi. Baba adaylarının \% 55 'i aile büyüklerinden bilgi edindiği belirlendi (Tablo II).

Tablo I: Anne ve babaların tanıtıcı özelliklerine göre dağılımı (n=200)

\begin{tabular}{|c|c|c|c|}
\hline \multicolumn{2}{|c|}{ Anne ve babaların tanımlayıcı özellikleri } & \multirow{2}{*}{$\begin{array}{l}\begin{array}{l}\text { Anne n(\%) } \\
(\mathbf{n}=\mathbf{1 0 0})\end{array} \\
18(18.0)\end{array}$} & \multirow{2}{*}{$\begin{array}{l}\begin{array}{l}\text { Baba n(\%) } \\
(n=100)\end{array} \\
21(21.0)\end{array}$} \\
\hline Eğitimdurumu & ílkokul & & \\
\hline & Ortaokul & $30(30.0)$ & $25(25.0)$ \\
\hline & Lise & $26(26.0)$ & $34(34.0)$ \\
\hline & Üniversite & $26(26.0)$ & $20(20.0)$ \\
\hline \multirow[t]{2}{*}{ Çalışma durumu } & Evet & $22(22.0)$ & $97(97.0)$ \\
\hline & Hayır & $78(78.0)$ & $3(3.0)$ \\
\hline \multirow[t]{3}{*}{ Meslek türü } & Memur & $8(36.4)$ & $12(12.4)$ \\
\hline & $\dot{I} s ̧ ̧ I_{1}$ & $1(4.5)$ & $75(77.3)$ \\
\hline & Serbest & $13(59.1)$ & $10(10.3)$ \\
\hline \multirow[t]{2}{*}{ Sağlık güvencesi } & Var & $84(84.0)$ & $87(87.0)$ \\
\hline & Yok & $16(16.0)$ & $13(13.0)$ \\
\hline \multirow[t]{3}{*}{ Gelir düzeyi durumu } & Gelir gidere az & $38(38.0)$ & $27(27.0)$ \\
\hline & Gelir giderden denk & $57(57.0)$ & $70(70.0)$ \\
\hline & Gelir giderden fazla & $5(5.0)$ & $3(3.0)$ \\
\hline \multirow[t]{3}{*}{ En uzun süre yaşanılan yer } & $\dot{I l}$ & $48(48.0)$ & $58(58.0)$ \\
\hline & ilç̧e & $30(30.0)$ & $18(18.0)$ \\
\hline & Кӧу & $22(22.0)$ & $23(23.0)$ \\
\hline \multirow[t]{3}{*}{ Ortalamalar } & & $\begin{array}{c}\overline{\mathrm{X}} \pm \text { SS } \\
(\text { Min-Maks) }\end{array}$ & $\begin{array}{c}\overline{\mathrm{X}} \pm \text { SS } \\
(\text { Min-Maks) }\end{array}$ \\
\hline & Yaş & $\begin{array}{c}27.40 \pm 5.74 \\
19-46\end{array}$ & $\begin{array}{c}30.55 \pm 5.93 \\
19-46\end{array}$ \\
\hline & Evlilik yılı & $\begin{array}{c}5.38 \pm 4.72 \\
1-19\end{array}$ & $\begin{array}{c}5.82 \pm 5.25 \\
1-29\end{array}$ \\
\hline
\end{tabular}


Anne ve Baba Adaylarının Gebe Okuluna Katılma Durumları....

Tablo II: Anne ve baba adaylarının şu anki gebeliğe ilişkin özelliklerinin dağılımı (n=200)

\begin{tabular}{|c|c|c|c|}
\hline Özellikler & & $\begin{array}{l}\text { Anne }(n=100) \\
n(\%)\end{array}$ & $\begin{array}{l}\text { Baba }(n=100) \\
n(\%)\end{array}$ \\
\hline \multirow[t]{2}{*}{ Bu gebeliği isteme durumu } & Istedim & $94(94.0)$ & $91(91.0)$ \\
\hline & Istemedim & $6(6.0)$ & $9(9.0)$ \\
\hline \multirow[t]{2}{*}{ Bu gebeliği planlama durumu } & Planlı & $77(77.0)$ & $75(75.0)$ \\
\hline & Plansiz & $23(23.0)$ & $25(25.0)$ \\
\hline \multicolumn{4}{|c|}{ Anne ve babaların gebelik sürecinde bilgi kaynakları* } \\
\hline & Sağlık profesyonelleri & $67(67.0)$ & $46(46.0)$ \\
\hline & Aile büyükleri & $47(47.0)$ & $55(55.0)$ \\
\hline & Kitap/dergi & $22(22.0)$ & $14(14.0)$ \\
\hline & Internet & $40(40.0)$ & $42(42.0)$ \\
\hline & Akrabalar & $36(36.0)$ & $29(29.0)$ \\
\hline & Arkadaşlar & $6(6.0)$ & $7(7.0)$ \\
\hline
\end{tabular}

*Katılımcılar birden fazla cevap verdi.

Gebelerin ortalama gebelik sayısı $2.20 \pm 1.3$, doğum sayısı $1.46 \pm 0.79$, çocuk sayısı $1.42 \pm 0.73$, spontan abortus sayısı $1.20 \pm 0.50$ ve kürtaj sayısı $1.20 \pm 0.56$ olup mevcut gebelik haftası ortalamaları $35.75 \pm 2.66$ 'dir. Gebeler, gebelik izlemi için çoğunlukla doğum evi (\%92) ve aile sağlığı merkezine (\%78) başvurduğunu belirtti. Gebelerin\%17'si gebeliğinde problem yașadığını bildirdi (Tablo III). Tablo IV incelendiğinde gebe okuluna katı-

Tablo III: Gebelerin doğurganlık öyküsünün dağılımı (n=100) çoğunluğunun (\%66), baba adaylarının ise, \%79'unun gebe okuluna katılmadığı anlașıldı. Gebe okuluna katılan anne adaylarının \%26.5'i doğum korkusu, \%26.5'i bilgi alma ve \%17.6'sının bebek bakımı konusunda gebe okuluna katıldığı belirlendi. Gebe okuluna katılan baba adaylarının \%25'i bebek bakımı, \%25'i eșe destek olmak, \%25'i ebeveynlik ve \%25'inin bilgi almak amaciyla gebe okuluna başvurduğunu bildirdi. Gebe okuluna ka-

\begin{tabular}{lcc}
\hline OBSTETRÍK ÖYKÜ & $\overline{\mathbf{X}} \pm$ SS & Min-Maks \\
\hline Ortalama gebelik sayısı & $2.20 \pm 1.33$ & $1-7$ \\
Ortalama doğum sayısı & $1.46 \pm 0.79$ & $1-4$ \\
Ortalama çocuk sayısı & $1.42 \pm 0.73$ & $1-4$ \\
Ortalama spontanabortus sayısı & $1.20 \pm 0.50$ & $1-3$ \\
Ortalama ölü doğum sayısı & $1.0 \pm 0.00$ & $1-1$ \\
Ortalama kürtaj sayısı & $1.20 \pm 0.56$ & $1-3$ \\
Gebelik izlem başlama ayı & $1.63 \pm 1.08$ & $1-7$ \\
Gebelik haftası & $35.75 \pm 2.66$ & $30-40$ \\
& & $\mathbf{n}(\%)$ \\
& Sağlık evi & $10(10.0)$ \\
Gebelerin izlenim yer durumu & Aile sağllğı merkezi & $78(78.0)$ \\
& Doğumevi & $92(92.0)$ \\
Gebelikte problem durumu & Devlet hastanesi & $10(10.0)$ \\
Problem türü & Özel hastane & $26(26.0)$ \\
& Özel doktor & $11(11.0)$ \\
& Evet & $17(17.0)$ \\
& Hayır & $83(83.0)$ \\
\end{tabular}

lan ve katılmayan anne ve adayları ile yapılmıștır. Gebe okuluna anne adaylarının \%34'ünün, baba adaylarının $\% 21$ 'inin katıldığı tespit edildi.

Anne adaylarının \%68'i, baba adaylarının \%53'ü doğum öncesi, sonrası ve ebeveynliğe ilişkin süreçlerle ilgili bilgilerinin yeterli olduğunu bildirdi. Anne adaylarının tılmayan anne adaylarının \%19.5'i hastanenin konumu, \%19.5'i gerek görmemiş, \%20.7'si gebe okulunu bilmediği için ve \%17.1'i evdeki diğer çocukların bakımının aksamaması için gebe okuluna gidemediğini bildirdi. Gebe okuluna katılmayan babaların \%50.6'sı iş yoğunluğu, \%19.3'ünün gebe okulu uygulamasını duymadığı için 
Tablo IV: Anne ve baba adaylarının gebe okuluna katılma ya da katılmama özelliklerine göre dağılımı (n=200)

\begin{tabular}{|c|c|c|}
\hline Özellikler & $\begin{array}{c}\text { Anne n (=100) } \\
\text { n (\%) }\end{array}$ & $\begin{array}{c}\text { Baba n }(=100) \\
\text { n (\%) }\end{array}$ \\
\hline \multicolumn{3}{|c|}{ Doğum öncesi ve sonrası süreçle ilgili algılanan bilgi durumu } \\
\hline Yeterli & $68(68.0)$ & $53(53.0)$ \\
\hline Yetersiz & $5(5.0)$ & $9(9.0)$ \\
\hline Kısmen Yeterli & $27(27.0)$ & $38(38.0)$ \\
\hline \multicolumn{3}{|l|}{ Gebe okulu ile ilgili bilgi durumu } \\
\hline Evet & $45(45.0)$ & $41(41.0)$ \\
\hline Hayır & $55(55.0)$ & $59(59.0)$ \\
\hline \multicolumn{3}{|l|}{ Gebe okulunun öğrenildiği kaynak } \\
\hline Sağlık profesyonelleri & $29(67.4)$ & $25(71.4)$ \\
\hline Aile büyükleri & $4(9.3)$ & $2(5.7)$ \\
\hline İnternet & $4(9.3)$ & $2(5.7)$ \\
\hline Arkadaș & $6(14.0)$ & $6(17.1)$ \\
\hline \multicolumn{3}{|l|}{ Gebe okuluna katılma durumu } \\
\hline Evet & $34(34.0)$ & $21(21.0)$ \\
\hline Hayır & $66(66.0)$ & $79(79.0)$ \\
\hline \multicolumn{3}{|l|}{ Gebe okuluna katılma nedeni } \\
\hline Bebek bakımıyla ilgili bilgi almak & $6(17.6)$ & $5(25.0)$ \\
\hline Eşe destek olmak & --- & $5(25.0)$ \\
\hline Doğum korkusu & $9(26.5)$ & --- \\
\hline Süreçle ilgili bilgi almak & $9(26.5)$ & $5(25.0)$ \\
\hline Ebeveynlik & $5(14.7)$ & $5(25.0)$ \\
\hline Yeni doğanın sağlığı ve acil durumlar & $5(14.7)$ & --- \\
\hline \multicolumn{3}{|l|}{ Gebe okuluna katılmama nedeni } \\
\hline Hastanenin konumu & $16(19.5)$ & $9(10.8)$ \\
\hline İş yoğunluğu & $10(12.2)$ & $42(50.6)$ \\
\hline Gerek görmemek & $16(19.5)$ & $14(16.9)$ \\
\hline Uygulamadan bilgim yoktu & 17 (20.7) & $16(19.3)$ \\
\hline Evdeki diğer çocukların bakımı için & $14(17.1)$ & $2(2.4)$ \\
\hline Gebelikte yaşanan zorluklar & $9(11.0)$ & --- \\
\hline
\end{tabular}

ve \%16.9'u gerek görmediği için gebe okuluna gitmediği belirlendi (Tablo IV).

Anne adaylarından lise ve üniversite (\%50) mezunu olanların çoğunlukla gebe okuluna katıldığı saptandı. Baba adaylarından gebe okuluna katılmayanların \% 90.5 'i ilkokul mezunudur. Anne adaylarının eğitim durumunun ve gebe okuluna katılma durumlarında istatistiksel olarak anlamlılık saptandığı $(\mathrm{p}<0.05)$, anne ve babaların diğer sosyo demografik değișkenlerle gebe okuluna katılma durumları arasında istatistiksel anlamda herhangi bir farklılık olmadığı tespit edildi (Tablo V; $\mathrm{p}>0.05$ ).

\section{TARTIȘMA}

Anne ve baba adaylarının gebe okuluna katılma ve katılmama nedenlerini belirlenmek amacıyla gerçekleștirilen araştırmamızda anne ve baba adaylarının bilgi kaynakları genelde sağlık profesyonelleri, aile büyükleri ve internet olduğu bulundu. Benzer olarak bir araştırmanın sonuçları arasında babaların bilgi kaynaklarının büyük oranda sağlık profesyonelleri ve aile olduğu bulunmuştur (15). Başka bir araştırmada ise, doğum öncesi eğitim sınıflarına katılan hem anne hem de baba adaylarının gebelik süreciyle ilgili herhangi bir konuda bilgi gereksinimlerini internetten araștırdıkları belirlenmiştir (21). Gebelerin gebe okuluna katılma durumlarıyla ilgili görüşlerinin irdelendiği araştırmada danışmanlığın ebe ve hemşireler tarafından aldıkları bulunmuştur (7). 
Anne ve Baba Adaylarının Gebe Okuluna Katılma Durumları....

Tablo V: Anne ve babalarının sosyo demografik özelliklerine göre gebe okuluna katılma ya da katılmama durumlarının karşılaştırılması $(\mathrm{n}=200)$

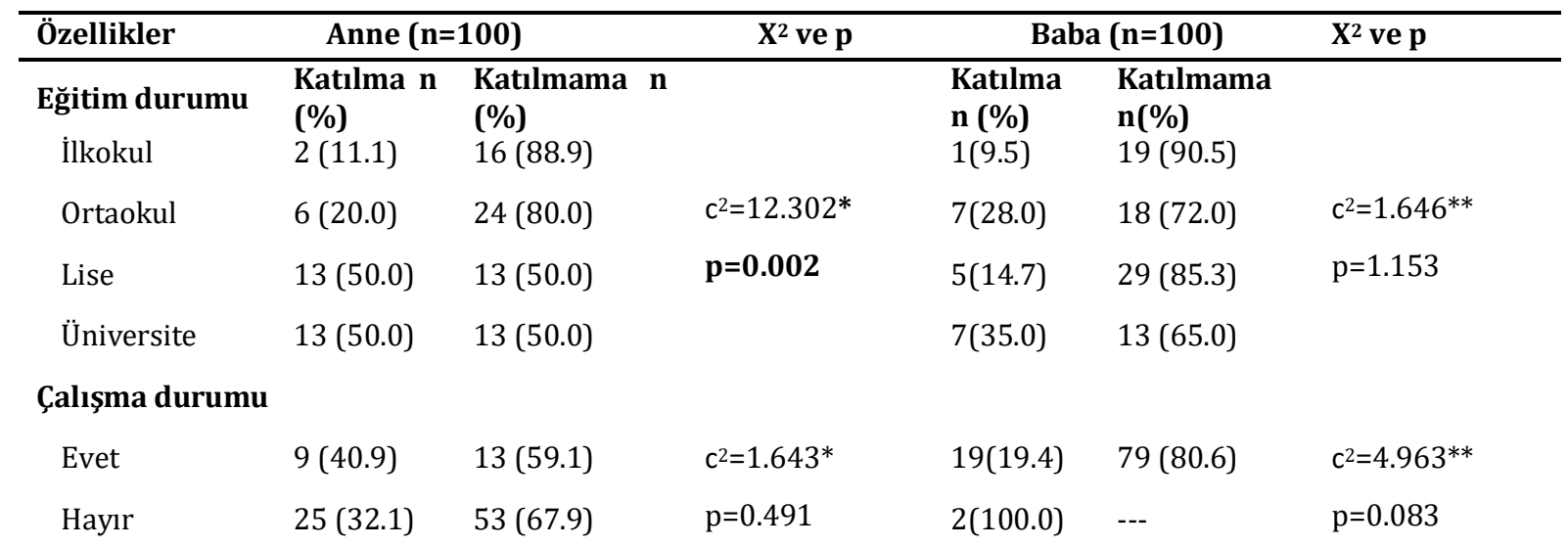

\section{Gelir düzeyi algısı}

$\begin{array}{lllllll}\mathrm{Az} & 10(10.0) & 28(28.0) & \mathrm{c}^{2}=3.539^{*} & 5(18.5) & 22(81.5) & \\ \text { Denk } & 23(23.0) & 34(34.0) & \mathrm{p}=0.05 & 15(21.4) & 55(78.6) & \mathrm{c}^{2}=0.254^{* *} \\ \text { Fazla } & 1(20.0) & 4(80.0) & & 1(33.3) & 2(66.7) & \mathrm{p}=0.773\end{array}$

Yaşanılan yer

$\begin{array}{lll}\text { Ill } & 16(33.3) & 32(66.7) \\ \text { İlçe } & 11(36.7) & 19(63.3) \\ \text { Köy } & 7(31.8) & 15(68.2)\end{array}$

$\begin{array}{llll}\mathrm{c}^{2}=0.502^{* *} & 9(15.3) & 50(84.7) & \\ \mathrm{p}=0.604 & 8(34.8) & 15(65.2) & \mathrm{c}^{2}=0.735^{*} \\ & 4(22.2) & 14(77.8) & \mathrm{p}=0.275\end{array}$

Sağlık güvencesi durumu

\begin{tabular}{lllllll} 
Var & $31(36.9)$ & $53(63.1)$ & $\mathrm{c}^{2}=0.390^{* *}$ & $18(20.7)$ & $69(79.3)$ & $\mathrm{c}^{2}=0.261^{* *}$ \\
Yok & $3(18.8)$ & $13(81.3)$ & $\mathrm{p}=0.730$ & $3(23.1)$ & $10(76.9)$ & $\mathrm{p}=0.699$ \\
\multicolumn{2}{l}{ Meslek türü durumu } & & & & & \\
Memur & $4(66.7)$ & $2(33.3)$ & $\mathrm{c}^{2}=0.829^{* *}$ & $4(33.3)$ & $8(66.7)$ & $\mathrm{c}^{2}=0.719^{* *}$ \\
İşci & $3(75.0)$ & $1(25.0)$ & $\mathrm{p}=0.621$ & $4(15.4)$ & $22(84.6)$ & $\mathrm{p}=0.412$ \\
Serbest & $2(16.7)$ & $10(83.3)$ & & $11(18.3)$ & $49(81.7)$ &
\end{tabular}

*Pearson Chi-Square. **Fisher Exact test. $\mathrm{p}<.05$

Lima-Pereira ve ark. (21) arastırmasında gebe okuluna katılan bireylerin sağlık bilgisi kaynağı olarak interneti kullandıkları tespit edilmiştir. Araştırmamızda bilgi kaynağı olarak çoğunlukla sağlık profesyonellerini tercih edilmesi ailelerin sağlık profesyonellerine güvenlerinden kaynaklanmış olabilir.

Araștırmamızda anne adaylarının eğitim durumunun gebe okuluna katılma durumlarını etkilediği, eğitim düzeyleri ilkokul ve ortaokul düzeyinde bulunan katılımcıların daha az gebe okuluna katıldıkları saptandı. Yapılan pilot bir çalışmada doğum öncesi eğitim gruplarına katılan babaların eğitim durumları lise ve üniversite düzeyindeydi (11). Ülkemizde yapılan başka bir çalışmada gebe okuluna dahil olan gebelerin eğitim durumlarının çoğunluğunun lise ve üniversite mezunu olduğu bulunmuştur (19). Gebe okulunda doğuma hazırlık eğitimi alan gebelerle yapılan çalışmada gebe okuluna katı- lanların çoğunluğunun lisans mezunu olduğu belirlenmiștir (13). Eggermont ve ark. (22)'nın araştırmasında ise, eğitim durumları düșük düzeyde olan baba adaylarının doğum ve sonrası süreçle ilgili bilgiye gereksinim duymadıkları belirlenmiştir. Bu sonuçlara göre, gebe okuluna katılmayan bireylerin gebe okulu konusunda farkındalıkları ve bilgileri yeterli düzeyde olmayabilir. Araştırmamızda beş yıla kadar evli olan genç bireylerin daha fazla gebe okuluna katıldıkları belirlendi. Slomian ve ark. (23) araştırmasında özellikle genç anne ve babaların bilgi ve destek gereksinimleri olduğunu tespit etmişlerdir. Bu bulgu genç katılımcılardan özellikle ilk defa anne baba olma deneyimleri konusunda hazırlıksız olmalarıyla ve bilgi arama davranışlarıyla ilișkili olabilir. Araştırmamızda anne adayları baba adaylarına göre gebe okuluna katılım oranı hem anne hem de baba adayları için düşük oranlarda olduğu bulundu. Gebe 
okuluna katılma durumlarını incelediği bir araştırmada kadınların yarısından fazlasının gebe okuluna katılmak konusuyla ilgilenmediğini belirtmişlerdir (24). Nash ve ark. (25) araştırmasında babaların doğum öncesi eğitim gruplarına katılma motivasyonları incelendiğinde cinsiyetçi söylemleri ve eril davranışları bulunan babaların gebe okuluna katılmaya karșı önyargılı oldukları bulunmuștur. Bașka bir araștırmada ise, doğum öncesi eğitim gruplarına katılım konusunda anne ve baba adaylarının ilgisiz oldukları tespit dilmiștir (11). Bu sonuçlara göre baba adaylarının gebe okullarına eșleri ile birlikte katılımlarının teşvik edilmesi ve gebe okullarının gerekliliği konusunda farkındalık arttırıcı etkin çalıșmalar yapılabilir. $\mathrm{Bu}$ çalışmalar, anne ve baba adaylarına bilgisel destek sağlamak yolu ile gerçekleştirilebilir.

Yapılan bu araștırmada, gebe okuluna katılan anne adayları daha çok doğum korkusu ve süreçle ilgili bilgi almak istemiş olup, baba adayları eșe destek olmak, süreçle ilgili ve bebek bakımıyla ilgili bilgi almak amacıyla gebe okuluna katılmıșlardır. Ebeveynlerin doğum öncesi dönemde bilgi gereksinimlerinin belirlendiği benzer bir araștırmanın sonuçlarında rutin bebek bakımı, eșe yardım etme, doğum ve sonrası süreçlerle ilgili bilgi almak istedikleri belirlenmiştir (26). Doğum öncesi eğitim programlarına ilişkin yapılan çalışmalarda katılımcıların doğum planı, ebeveynlik, bebek bakımı, bakıma katılma, gebelik ve benzeri konularda gebe okuluna katılmayı tercih ettikleri anlașılmıștır $(7,20)$. Bu doğrultuda, ebeveynlerin doğum öncesi eğitim gereksinimlerin belirlenmesi ile anne ve babaların ihtiyaca yönelik bilgi ve beceri kazandırılmasını kolaylaștırabilir.

Gebe okuluna katılmayan babaların çoğunluğu iş yoğunluğu ve gebe okulu uygulamasından haberdar olmadıkları nedeniyle gebe okuluna katılmamıșlardır. Deibel ve ark. (11) babalar eșlerine yardım etmek ve bakıma dâhil olmak konusunda istekli olsalar da, bu bilgiyi nasıl edineceklerini ve gebe okulu uygulamalarını bilmediklerini bildirmișlerdir. Nasiri ve ark. (15)'nın araștırmasında babaların doğum öncesi dönemdeki eğitimlere katılmalarının istendik düzeyde olmadığı ve doğum öncesi eğitimlerin katılma zamanlarının tatil günlerinde olması ile eğitim sonuçlarının daha olumlu olduğu bulunmuştur. Bașka bir araștırmada ise, doğum öncesi eğitimlere erkeklerin katılmalarını olumsuz etkileyen durumların bilgi eksikliği olduğu belirlenmiștir (16). Bu nedenle gebe okulu eğitim saatlerinin ailelerin vardiya saatlerine uygun düzenlenmesi, gebe okulu uygulamasının ev ziyaretleri ya da tanıtım çalıșmalarının duyurulması ile bireylerin gebe okulu programlarına katılım durumlarını olumlu etkileyebilir.

\section{Araștırmanın Sınırlılıkları}

$\mathrm{Bu}$ araştırmanın sınırlılıkları araştırmaya katılan anne ve baba adaylarının verdiği bilgilerin doğruluğu kapsamındadır. Öte yandan belli bir zaman diliminde araștırma kapsamına dâhil edilen tüm alınan bireylerden elde edilen veriler örnekleme dâhil edilen bireyleri temsil edebilir.

\section{SONUC VE ÖNERILER}

Sonuçlarda anne ve babaların büyük oranda gebe okuluna katılmadığı belirlendi. Katılımclların çoğunluğu gebe okulu hakkında yeterli bilgi sahibi olmadıklarını, bilgi gereksinimleri olduğunda ise, daha çok güvendikleri sağlık profesyonellerine, yakın çevrelerine ve internete danıştıkları belirlendi. Anne adayları babalara benzer olarak katılmama nedenleri arasında hastanenin konumunun uzaklı̆̆l, gerek duymamak ve bilgi eksikliği konusunda hemfikirdi. Baba adayları ayrıca yoğum iş yaşantısı nedeniyle gebe okuluna katılma konusunda isteksiz ve kararsız olduklarını bildirdi. Bu sonuçlara göre şu önerilerde bulunulabilir; aileler gebe okulunun önemi hakkında bilgilendirilmeli, gebe okulu eğitim içerikleri, saatlerinin ailelerin gereksinimlerine göre düzenlemeli, ailelerin gebe okuluna katılımını teșvik edici ve kolaylaştırıcı çalışmalarda sağlık profesyonelleri aktif olarak görev almalıdırlar.

\section{KAYNAKLAR}

1. World Health Organization. WHO recommendations: Intrapartum care for a positive child birth experience. 2018. https://www.who.int/ publications/i/item/9789241550215; Erişim tarihi: 10.09.2019.

2. WHO. Improving health system performance. WHO recommendation on antenatal care contact schedules. 2016. extranet.who.int/rhl; Erișim tarihi: 10.09.2019.

3. T.C. Sağlık Bakanlığı. Türkiye Halk Sağlığı Kurumu Kadın ve Üreme Sağlığı Daire Başkanlığı. Doğum Öncesi Bakım Yönetim Rehberi. 2018. https:// hsgm.saglik.gov.tr/depo/birimler/ Kadin_ve_Ureme_Sagligi_Db/dokumanlar/rehbler/ dogum_oncesi_bakim_08-01-2019_1.pdf; Erişim tarihi: 10.09.2019.

4. Rathfisch G. Doğal Doğum Felsefesi (2. Baskı). Nobel Tıp Kitabevleri, İstanbul 2018; ss1-17.

5. Serçekus P, Mete S. Effects of antenatal education on maternal prenatal and postpartum adaptation. J Adv Nurs 2010;66(5):999-1010.

6. T.C. Sağlık Bakanlığı. Türkiye Halk Sağlığı Kurumu Kadın ve Üreme Sağlığı Daire Bașkanlığı. Gebe Bilgilendirme Sınıfı Eğitimci Kitabı. Türkiye Halk Sağlığı Kurumu Kadın ve Üreme Sağlığı Daire Başkanlığı, Ankara 2013; ss 2-17.

7. Gönenç IM, Cakırer Calbayram N. Gebelerin, gebe okulu programı hakkındaki görüșleri ve eğitim sonrası deneyimleri. J Human Sci 2017;14(2):16091620 .

8. Kania-Richmond A, Hetherington E, McNeil D, et al. The impact of introduction centering pregnancy in a community health setting: A qualitative study of experiences and perspectives of health center clinical and support staff. Matern Child Health J 2017;21 (6):1327-1335.

9. Sharma J, O'Connor M, Rima Jolivet R. Group antenatal care models in low and Middle income countries: A systematic evidence synthesis. Reprod Health 2018; 15(1):38.

10. Dinç H, Yazıcı S, Yılmaz T, Günaydın S. Gebe eğitimi. HSP 2014;1(1):68-76.

11. Deibel M, Zielinski RE, Shindler Rising S, et al. Where are the dads? A pilot study of a dads-only session in group prenatal care. J Perinat Neonatal Nurs 2018;32(4):324-332.

12. Firouzan V, Noroozi M, Farajzadegan Z, Mirghafourv and $M$. Barrierstomen's participation in perinatal care: A qualitative study in Iran. BMC Pregnancy Child Birth 2019;19(1):45. 
Anne ve Baba Adaylarının Gebe Okuluna Katılma Durumları....

13. Yılmaz Esencan T, Karabulut Ö, Demir Yıldırım A ve ark. Doğuma hazırlık eğitimi alan gebelerin doğum şekli, ilk emzirme zamanı ve ten tene temas tercihleri. FNHD 2018; 26(1):31-43.

14. VeringaIK de Bruin EI, Bardacke N, et al. 'I've changed my mind.', Mindfulness-Based Childbirth and Parenting (MBCP) for pregnant women with a high level of fear of childbirth and their partners: Study protocol of the quasi-experimental controlled trial. BMC Psychiatry 2016; 16(1):377.

15. Nasiri S, Vaseghi F, Moravvaji SA, Babaei M. Men's educational needs assessment in terms of their participation in prenatal, childbirth and postnatal care. J Educ Health Promot 2019;8:59.

16. Mortazavi F, Keramat A. The study of male involvement in prenatal care in Shahroud and Sabzevar. Iran Qom Univ Med Sci J 2012;6: 66-74.

17. Polite DF, Beck CT. Nursing Research: Methods and Principles (9th ed). Lippincott Publishers, Williams \&Wilkins, Philadelphia 2012; pp. 512-515.

18. Cohen J. Statistical Power Analysis for the Behavioral Sciences (2nd ed). Lawrence Erlbaum Associates, New York 1988; pp. 274-87.

19. Turgut N, Güldür A, Çakmakçı H ve ark. Gebe okulunda eğitim alan gebelerin bilgi düzeyleri üzerine bir araştırma. JAREN2017;3(1):1-8.

20. Soriano-Vidal FJ, Vila-Candel R, Soriano-Martín PJ, Tejedor-Tornero A,Castro-Sánchez E. Theeffect of prenatal education classes on the birth expectations of Spanish women. Midwifery 2018;60:41-47.

21. Lima-Pereira P, Bermúdez-Tamayo C, Jasienska G. Use of the internet as a source of health information amongst participants of antenatal classes. J Clin Nurs 2012; 21(3):322-330.

22. Eggermont K, Beeckman D, Van Hecke A, et al. Needs of fathers during labour and childbirth: A crosssectional study. Women Birth 2017;30(4):188-197.

23. Slomian J, Emonts P, Vigneron L, et al. Identifying maternal needs following childbirth: A qualitative study among mothers, fathers and professionals. BMC Pregnancy Childbirth 2017;17(1):213.

24. Mc Donald SD, Sword W, Eryüzlü LN, et al. Why are half of women interested in participating in group prenatal care? Matern Child Health J 2016;20 (1):97-105.

25. Nash M. Addressing the needs of first-time fathers in Tasmania: A qualitative study of father-only antenatal groups. Aust J Rural Health 2018; 26(2):106111.

26. Barimani M, Forslund Frykedal K, Rosander M, Berlin A. Childbirth and parenting preparation in antenatal classes. Midwifery 2018;57:1-7. 